\title{
Analysis of Factors Affecting Subjective Well-Being of the Couple Adopting a Child in Darul Imarah Sub-District of Aceh Besar Regency in 2021
}

\author{
Junizar $^{1^{*}}$, Rika Dewi $^{2}$ \\ ${ }^{1}$ Akademi Keperawatan Kesdam, Akademi Kebidanan Saleha, Aceh, Indonesia \\ *Corresponding Author: Junizar, junizar257@gmail.com
}

\begin{abstract}
For Acehnese, having children is a dream of every family. Therefore, if a couple who has been married for more than two years has not had children, conflicts often occur in the family. Generally, wives are blamed as the main cause of having no children even though that is not necessarily true. Moreover, in Aceh, husbands are often embarrassed to see a doctor since they have fear of knowing the real cause of having no children. This condition has turned out to be a parameter of a person's success in a marriage and even causes conflicts that might result in a divorce. This study aimed to examine various factors that affect the subjective well-being of a married couple adopting a child in Darul Imarah Sub-district of Aceh Besar Regency. A qualitative design was employed in this research. The respondents were a married couple and an informant as a source of triangulation of information. Those respondents were chosen by using a purposive sampling technique. The research data were collected in July 2021 through interviews and observations, and the data analysis was carried out using data reduction, data display, and verification. The results showed that the couple has adopted a child, and they have been happy. They have always understood each other's strengths and weaknesses, actively communicated, supported each other, and made decisions according to mutual needs, so their subjective wellbeing has been stable. Two factors affecting the subjective well-being in this couple were internal factors including their optimism, self-esteem, and religious values, and external factors including wife's health regarding having undergone cyst surgery, the wife's age of 40, and support from a big family.
\end{abstract}

Keywords: subjective well-being, married couples, offspring.

\section{Introduction}

Subjective well-being is an individual's evaluation of his life, including affective and cognitive evaluations. Diener (2009) described that some evaluations can be done through a cognitive assessment, including life satisfaction and emotional responses to particular events, such as feeling positive emotions. The presence of emotional experiences is also included as a component of subjective well-being. The way individuals evaluate their lives consists of several variables such as life and marital satisfaction, low levels of depression and anxiety, the presence of emotions, and a positive mood. Thus, subjective well-being is an individual's evaluation of the quality of life that is carried out through cognitive evaluation (life satisfaction), affective evaluation (presence of positive emotions and low level of negative emotions).In marriage, having a child is generally highly coveted because it is believed to be able to improve the quality of a family. For some people, it might be one of the marriage goals. Every married couple certainly wants to have a child. The presence of a child is expected to bring more happiness to the family.

According to Diener (2009), since subjective well-being is a person's evaluation of his life, it can be carried out in the form of both a cognitive evaluation including life satisfaction and emotional evaluation including the frequency of experiencing positive effect (pleasant feeling) and negative affect (unpleasant feeling). Subjective well-being is 
one of the predictors of an individual's quality of life because it can affect the individual's success in various life aspects. Individuals with a high level of subjective well-being will feel more confident, maintain better social relationships and show better work performance. In addition, in stressful situations, individuals with high levels of subjective well-being can adapt and cope more effectively with these conditions so that they might have a better life (Tamir in Dewi \& Utami, 2008).

Diener (2009) also described that subjective well-being is divided into three main aspects, a) Cognitive Component (Life Satisfaction): The cognitive component consists of an evaluation of life satisfaction. Life satisfaction is a subjective condition of a personal situation about feeling happy or unhappy as a result of the existing courage or needs, and it is also associated with reality. An individual that can accept himself and his environment positively will feel satisfied with his life. The cognitive component of subjective wellbeing also includes various domains of satisfaction, such as those related to self, family, peer groups, health, finance, work, and leisure. b) Positive Affect: Individuals can be said to have positive subjective well-being if they frequently experience positive emotions such as being attentive, interested, alert, excited, enthusiastic, inspired, proud, strong, and active. c) Negative Affect: Individuals can be said to have negative subjective well-being if they often experience negative emotions such as sadness, hostility, irritability, fear, shame, guilt, and anxiety.

Various other studies, such as a study conducted by Lucas \& Schinmack (2009), have found the following factors associated with subjective well-being. 1) Personality: Personality is one of the internal factors that play an important role in subjective wellbeing. Positive affect, negative affect, and life satisfaction which were fairly stable over time were highly correlated with psychophysiological indicators and personality traits such as extraversion and neuroticism. This theory is supported by Diener (2009) that mentions that several personality variables show a consistent relationship with subjective well-being. High self-esteem is one of the strongest predictors of subjective well-being. 2) Selfacceptance: Studies conducted in the late 1940s were mostly under the influence of the humanistic perspective on self-acceptance, and it has been confirmed that high levels of self-acceptance are associated with positive emotions, satisfying social relationships, achievement, and adjustment to negative life events. Self-acceptance is a factor related to subjective well-being. If individuals accept themselves, they can adjust to any difficult situation, keep feeling valued, experience fewer negative emotions, show more positive emotions, and become satisfied with their lives in supporting their well-being. 3) Employment Status: Employment status is known to greatly influence subjective wellbeing. Unemployment is strongly associated with a negative impact on the measurement of an individual's life satisfaction. 4) Health Status: Both physical and mental health status are correlated to subjective well-being, and it has been proven that changes in disability status led to changes in life satisfaction.5) Social Relations: Social contact is one of the most important controllers for subjective well-being since it strongly affects life evaluation as well as positive and negative affect.

Marriage is a stage of development in a person's life that gives happy feelings such as feelings of belonging, being protected, and being safe. There are several reasons people get married, namely willingness to share, needs of love and closeness, and needs for getting support from others, having a partner to have a sexual life, and having children. When one of those goals has not been achieved, some married couples often start to worry and feel unhappy. However, Trihandayani (2015) explained that not all couples are unhappy with their marriages and divorce when they have no children. Many couples continue to maintain a happy marriage for various other reasons. For most married couples, the value of children is a community assessment system related to the presence of children in a 
family. Typical married couples also believe that having children is a complement to married life. In addition, having children is often seen as a marriage goal or an achievement. Those who have no children because of certain problems related to their reproductive system are called infertile. Infertility is the inability of a married couple to have biological children (Kustanti, 2016).

WHO has defined infertility as a problem of the reproductive system which can be seen through the inability to be pregnant after regularly having sexual intercourse at least twice or three times for 12 months or more without using any contraception method. Oktarina (2014) also states that a couple is called infertile because of having no children after a year of marriage. A research was conducted by Kustanti \& Mardiyan (2016). It was about determining the marital satisfaction in married couples who have not had any children. This study employed a qualitative method with a phenomenological approach, and Interpretative Phenomenological Analysis (IPA). The data were collected through a semi-structured interview. This study was conducted on two married couples who have not had children, with 4 years of marriage. The samples were selected using a non-probability sampling method with a purposive sampling technique. The results showed that the absence of children affected the marital satisfaction of some of them. They experienced sadness, loneliness, discomfort, and boredom in marriage because of having no children. In addition to the absence of children, other factors that affected the subjects' marital satisfaction are relationships with their spouses, expectation mismatches, and the unachieved goals of marriage. Marital satisfaction has been seen as the fulfillment of all needs in a marriage.

Based on the results of an interview with one of the subjects, one of the couples was unhappy because of having no children. Even though they have adopted a child, they were still unhappy. They experienced more negative emotions in their marriage. While the other couple, according to the results of the pre-survey, kept trying to have their children through both medical treatments and traditional therapies. There was also another couple that adopted a child and felt happy about it while trying to have their children. Another couple was happy and understood each other even though the marriage has not yet blessed with children. Hence, we tried to examine more deeply other married respondents who have not had any children as the focus of this research. Because almost all people believe that when a married couple is unable to have children, the couple's subjective well-being is likely unstable. Based on the background described above, the focus of this research can be formulated as "What are the factors that affect the subjective well-being of a married couple with an adopted child in Darul Imarah Sub-district of Aceh Besar Regency in 2021?

\section{Method}

A qualitative research method was used by the researchers because the purpose of the research was to examine various factors affecting the subjective well-being of a married couple with an adopted child in Darul Imarah Sub-district of Aceh Besar Regency. In conducting this qualitative research, the data were collected through interviews based on the relevant guidelines. Since this research used a phenomenological approach, it examined visible behaviors. Specifically, the researcher wanted to examine the visible behaviors of the respondents regarding the subjective well-being of married couples, to describe their lived experiences, and to explore the structure of consciousness in the respondents' experiences to describe, understand, and interpret the meaning of the experiences.

Qualitative research cannot be separated from respondents and data sources or research informants. The respondents can be defined as individuals or collective groups who will be asked for information needed by data seekers. In collecting data from respondents through direct interviews, a researcher must be really thorough. 
In choosing the respondents and informants in this study, the researchers used a purposive sampling technique, which according to Sugiyono (2013) is the selection of a group of subjects based on certain characteristics or traits that are considered to have a close relationship with the previously known characteristics or traits of the population. The characteristics or traits were being married couples who have been married for more than ten (10 years), having no children, and coming from Darul Imarah Sub-district of Aceh Besar Regency

To be close to the respondents, before conducting the interview, the researcher first collected the information related to the general description of the respondents and the informant. The information can be seen in the following tables.

Table 1. General Description of the Respondents

\begin{tabular}{llll}
\hline No & General Description & $\begin{array}{l}\text { Respondent 1 } \\
\text { (Wife) }\end{array}$ & $\begin{array}{l}\text { Respondent 2 } \\
\text { (Husband) }\end{array}$ \\
\hline 1 & Name (Initial) & IV & RG \\
2 & Age (years) & 40 & 45 \\
3 & Birth order & The $3^{\text {rd }}$ child of 5 siblings & The $2^{\text {nd }}$ child of 4 siblings \\
4 & Gender & Female & Male \\
5 & Religion & Islam & Islam \\
6 & Length of marriage & 15 years & 15 years \\
7 & Educational & Senior high school & Undergraduate degree \\
8 & background & & Civil servant \\
9 & Occupation & Housewife & No \\
10 & Parent(s) in law & No & Yes \\
\hline
\end{tabular}

Table2. General Description of the Informant

\begin{tabular}{lll}
\hline No & General Description & Informant \\
\hline 1 & Name (Initial) & RF \\
2 & Age (years) & 43 \\
3 & Birth order & The $2^{\text {nd }}$ child of 5 siblings \\
4 & Gender & Female \\
5 & Religion & Islam \\
6 & Ethnicity & Aceh \\
7 & Educational background & Senior high school \\
8 & Occupation & Housewife \\
9 & Relation with the Respondent & Younger sibling \\
10 & Address & Darul Imarah Sub-district-Aceh Besar Regency \\
\hline
\end{tabular}

\section{Results and Discussion}

The results of this research showed the description of subjective well-being as well as the aspects and factors affecting the subjective well-being of the respondents. For clearer information, the researchers compiled the data in the form of an interpersonal analysis table. The following Table 3 explains the interpersonal analysis of the respondents.

Table3. Interpersonal Analysis of the Respondents

\begin{tabular}{ccl}
\hline No & \multicolumn{1}{c}{ Research Focuses } & \multicolumn{1}{c}{ Respondents } \\
\hline 1 & Description fo Subjective Well-being & $\begin{array}{l}\text { The respondents who were a married couple and had } \\
\text { no biological child were happier after adopting a } \\
\text { child. Therefore, they have stable well-being } \\
\text { regarding their marriage. }\end{array}$ \\
2 & $\begin{array}{l}\text { Aspects of Subjective Well-being } \\
\text { Life satisfaction }\end{array}$ & $\begin{array}{l}\text { The respondents were satisfied with their marriage } \\
\text { life despite their "weakness", which was having no }\end{array}$ \\
\hline
\end{tabular}


Positive Affect

Negative Affect

3 Factors Affecting Subjective Wellbeing External Factors

Internal Factors biological children. They understood that well-being is not only about having a biological child, and they were happy with an adopted one. Hence, they could be said to have life satisfaction as one aspect of stable subjective well-being.

Since the couple had stable subjective well-being and maintained good two-way communication in their household, they experienced more positive emotions. They were found to have a positive effect as one aspect of stable subjective well-being.

Very few negative emotions were found among the couple. They adapted well to their conditions, including the fact that they had to adopt a child. Since they experienced less negative affect, they were considered to have stable well-being regarding their marriage.

The wife ever had a cyst surgery that made it difficult to get pregnant. Meanwhile, the husband was often busy with the job that made him tired. Regarding the support from the family, even though both respondents' parents have passed away, their siblings have always given them support, especially to have children. Based on the results of the study, it was found that these respondents were able to have stable subjective well-being with their partners.

The husband was always optimistic, and he believed in religious values. Therefore, the marriage was always filled with happiness. Even though both of the respondents often got negative judgments from others because of having no children they maintained their happiness by being not negatively unaffected. With these supporting internal factors, the respondents were able to have stable subjective wellbeing with partners.

Many factors affect the ability to find happiness in a family. According to Maika (2009), the factors that can affect happiness include life aspirations and expectations and the ways to achieve them. In a family, each individual needs to demonstrate good relations or communication. Communication in a family is influenced by several factors, including words and terms used, mood, physical condition, tone of voice, mimic/movement, and personality/temperament, and the members' mindset which is the most important one.

The same thing was also expressed by Ariati (2010). She mentions the factors that influence subjective well-being which include positive self-esteem, self-control, extraversion, optimism, positive social relations, and meaning as well as purposes in life. Meanwhile, according to (Diener et al., 2009) demographic factors such as health, income, and educational background also affect a person's subjective well-being.

Furthermore, Walgito (2017) explains that marriage is the union of a man and a woman as husband and wife to form a family. Sinceboth of them have their own fully formed personality, some adjustments, mutual sacrifices, mutual understanding must be realized by both parties. In this regard, the role of communication in the family becomes very important. Both the husband and the wife must communicate well to avoid misunderstandings. This can be achieved by two-way communication.

Every individual wants a prosperous family, and there are many factors associated with a person's subjective well-being. With material and spiritual needs fulfilled, a person might feel a state of well-beingand enjoy life naturally and pleasantly. However, the reality may be different for some people. In a family in which all needs are completely fulfilled, the members might not have well-being. In this case, determining what the real meaning of wellbeing is not an easy task. This condition occurs because everyone in a family has their way of 
interpreting their well-being. Because well-being is subjective, it could be, as has been said before, that even though all of their needs are fulfilled, some people may still feel unhappy while some others might feel comfortable when facing poverty (Handayani, 2018).

In addition, researchers found that educational level has a positive influence on someone's subjective well-being. It was proven by the husband that had a good educational background and understood and his wife's needs well. He was able to understand and adapt to all problems in the family. According to the OECD (2013), the factors that affect the subjective well-being of individuals include demographic factors and environmental factors, namely gender, age, education, income, marriage, job satisfaction, religion, health, and leisure time.

Hasbalah (2007) states that one of the keys to success and happiness in a family is the ability to understand each other among the husband and wife. In this case, it is very necessary to complement and remind each other. The couple is also expected to accept each other's weaknesses and strengths, to give mutual encouragement and advice, and also help each other. They should not blame each other.

In general, religious people tend to have more stable and specific well-being. Participation in religious service, an affiliated relationship with God, and prayers were associated with higher levels of subjective well-being. There have been many studies where subjective well-being is significantly correlated with religious beliefs (Eddington and Shuman, 2008). According to Eddington and Shuman (2008), after controlling the age factor, income, and marital status, subjective well-being is related to the relationship with God, praying experiences, and participation in religious aspects. Religious experiences provide meaning in life, including in facing crises.

Based on the results of the research presented above, several factors affect subjective well-being in married couples having no children that adopted a child, including:

1. Age

The more mature the age, the more mature the way of thinking of an individual is supported by the experiences gained. As can be seen from the respondents of this research, both the husband and the wife who were above 40 years old, had a positive mindset with various life experiences and strong religious values that allowed them to find happiness in life. In this process, both the age of the individuals as well as the length of the marriage could be very influential in achieving happiness

\section{Education}

Different levels of education and knowledge might produce different attitudes and ways of thinking. As the researchers found in the respondents, the husband was welleducated while his wife only graduated from high school. Because the husband's level of education was higher than his wife's, the husband could protect his wife when she was sad or angry. The respondent's husband could guide his wife.

3. Communication

It is the ability to convey understandable messages to partners. Every couple should understand their household condition and get to know each other's physical and emotional conditions, habits, interests, hobbies, and so on. Among these respondents, the researchers found good communication. Even though they have not had any biological child, the atmosphere of their household was happy with a child that they adopted.

4. Children

The happiness of a married couple is not only about having children. In these respondents who have no biological children, the researchers found happiness and satisfaction. They were not young anymore and were likely to be at risk if they wanted to have biological children. Therefore, they adopted a child, and the adoption process was under their expectations. It made them happier. This means that having biological children is not the only reason to feel happiness in a marriage. There are many other ways that married couples can find to feel happiness, such as doing household activities together, hanging out in cafes together, and looking for more useful activities. All couples can be happy, and the ways to be happy might be different for different couples.

5. The religious factor

The couple could understand that their condition in which they did not have a biological child yet was a gift from God. Despite the health problem experienced by the wife that could not support them to have biological children, both of them never gave up, and they even adopted a child and were happy about it. Hence, their subjective well-being was stable. 


\section{Conclusions}

According to the results of this research, the subjective well-being of the respondents was supported by many factors, such as the mature husband, the high level of education of the husband, the religious values preserved by the couple, their mutual communication, and their awareness of each other's mutual needs. Their stable subjective well-being could also be seen through the existence of more happiness and harmony in their marriage after adopting a child. It could also be concluded that both the husband and the wife adapted well in terms of each other's personalities. They could mutually understand their needs and moods. They have been satisfied with what God has given them. Their spirit of life could not also be separated from the support received from their big family. Thus, the respondents could have stable subjective well-being, especially regarding their household.

\section{References}

Ariati, J. (2010). Subjective well-being (kesejahteraan subjektif) dan kepuasan kerja pada staf pengajar (dosen) di lingkungan fakultas psikologi universitas diponegoro. Jurnal Psikologi Undip, 8(2), 117-123.

Diener, E. (2009). The Science of Subjective Well-Being: The Collected Works of Ed Diener. Illinois: Springer.

Dewi, P.S.\&Utami, M.S.(2008). Subjectitive Well Being Anak Dari Orang Tua Yang Bercerai. Jurnal Psikologi Fakultas Psikologi Universitas Gadjah Mada, 35(2), 194212.

Eddington, N. \& Shuman, R. (2008). Subjective well-being (happiness). http://www.texcpe.com/html/pdf/ca/ca-happiness.pdf

Handayani, A., Yulianti, P.D., \& Ardini, S.N. (2018). Membina Keluarga Sejahtera Melalui Penerapan 8 Fungsi Keluarga. J-ABDIPAMAS (Jurnal Pengabdian Kepada Masyarakat), 2(1), 76-80.

Hasbalah. (2007). Empat Puluh Cara Mencapai Keluarga Bahagia. Jakarta: Gema Insani

Lucas, R, E \&Schinmmack, U. (2009). Income and Well Being: How Big is The Gap Between the Rich and The Poor? Journal. Res. Pers.,43, 75-78.

Maika, A. (2009). Mengukur Kemiskinan Subjektif di Indonesia: Eksplorasi Faktor yang Membuat Seseorang Merasa Miskin. Center for Population and Policy Studies Gadjah Mada University.

OECD (Organization for Economic Co-Operation and Development).(2013). OECD Guidelines on Measuring Kesejahteraan subyektif. Paris: OECD Publishing.

Sugiyono, (2013). Metode Penelitian Kombinasi (Mixed Methodes). Bandung: CV. Alfabeta.

Walgito, B. (2017). Bimbingan dan Konseling Perkawinan. Yogyakarta: Andi. 